\title{
Synthesis of Brushite from Phophogypsum Industrial Waste
}

\author{
Imad Yassine ${ }^{\mathbf{1}}$, Meryeme Joudi ${ }^{1}$, Houyem Hafdi ${ }^{1}$, Badreddine Hatimi ${ }^{\mathbf{1}}$, Jihane Mouldar ${ }^{\mathbf{1}}$, Meryem \\ Bensemlali ${ }^{1}$, Hamid Nasrellah ${ }^{1}$, Moulay Abderrahim El Mahammedi ${ }^{2}$, Mina Bakasse ${ }^{1, *}$ \\ 1 Laboratory of Bioorganic, Organic Chemistry and Environment, Faculty of Sciences, University Chouaib Doukkali, 24 \\ 000 El Jadida Morocco; minabakasse@yahoo.fr (M.B.); \\ 2 Sultan Moulay Slimane University, Laboratory of Chemistry, Modeling, and Environmental Sciences, Polydisciplinary \\ Faculty, 25000 Khouribga, Morocco; elmhammedi@yahoo.fr (M.A.E.M.); \\ Correspondence: minabakasse@yahoo.fr (M.B.);
}

Received: 3.06.2021; Revised: 5.09.2021; Accepted: 10.09.2021; Published: 19.11.2021

\begin{abstract}
Dicalcium phosphate dihydrate (DCPD) nanoparticles, also known as brushite, are considered an important bioceramic compound. In this study, brushite was prepared from Moroccan phosphogypsum (PG) using a new sol-gel method. A two-step technique undergoes the synthesis of brushite, the preparation of anhydrite from PG followed by adding phosphoric acid in the presence of sodium hydroxide. The morphology, the chemical composition, and the crystallites size were obtained using Scanning Electron Microscopy (SEM-EDAX), X-ray diffraction (XRD), and Fourier transform infrared spectroscopy (FTIR), respectively. According to the Debye-Scherrer equation, these characterization methods indicated that the synthesized brushite was highly pure according to the $\mathrm{Ca} / \mathrm{P}$ ratio of 1.14 and an average crystallites size estimated at $66 \mathrm{~nm}$. These results proved that the brushite was successfully synthesized from Moroccan phosphogypsum.
\end{abstract}

Keywords: brushite, phosphogypsum, nanoparticles.

(c) 2021 by the authors. This article is an open-access article distributed under the terms and conditions of the Creative Commons Attribution (CC BY) license (https://creativecommons.org/licenses/by/4.0/).

\section{Introduction}

Dicalcium phosphate dihydrate (DCPD), also called brushite, consists of three major elements: calcium, phosphorus, and oxygen. It is considered the main compound of the bones and teeth of vertebrates, including most human hard tissues. Some of these phosphates have cationic and/or anionic substitutions leading to many forms of structures. Due to their composition and availability, they have gained significant importance in various fields of science such as biology, chemistry, health, and medicine, including biomineralization [1-6].

The most common forms of Calcium phosphate phases studied for bio-functional applications include hydroxyapatite $\left(\mathrm{HA}, \mathrm{Ca} 10\left(\mathrm{PO}_{4}\right)_{6}(\mathrm{OH})_{2}\right)$, dicalcium phosphate anhydrous (DCPA, $\mathrm{CaHPO}_{4}$ ), amorphous calcium phosphate (ACP), tetra calcium phosphate (TTCP, $\mathrm{Ca}_{4}\left(\mathrm{PO}_{4}\right)_{2} \mathrm{O}$ ), Dicalcium phosphate dihydrate (DCPD, CaHPO $\mathrm{CH}_{2} 2 \mathrm{H}_{2} \mathrm{O}$ )[7,8]. Brushite is naturally present in the pathological form of kidney stones or the form of arthritis and cavities. It is also found in guano-rich caverns and is formed by the interaction between a phosphate solution derived from guano, calcite, and clay at low $\mathrm{pH}[9,10]$ or by the interaction of phosphate solution and limestone rocks or blocks buried inside the guano [11]. Brushite is used for various applications, particularly in the biomedical field and the food industry [12]. DCPD phosphate can contain several other ionic elements in its structure, either by doping, 
substituting calcium, or substituting phosphate groups [13-16]. Synthesis of brushite include precipitation of emulsions[17-20], crystallization of solutions[21-23], sol-gel [24], hydrothermal synthesis [25-28], microwave-assisted methods [28-30], chemical deposition [31-35], electrodeposition [36-40], and mechanic-chemical synthesis [41]. The method used in this study is a sol-gel reaction due to its simplicity, low cost, and ease of application in industrial production [42]. In this work, a new sol-gel technique was applied to syntheses the brushite from Moroccan phosphogypsum. The obtained product was dried at $105^{\circ} \mathrm{C}$ and was characterized.

\section{Materials and Methods}

\subsection{Characterizations methods.}

The structure was examined using an X-ray diffractometer (XRD X'Pert Pro MPD of Panalytical using $\mathrm{Cu} \mathrm{K} \alpha$ radiation $\left(\lambda=1.54 \mathrm{~A}^{\circ}\right)$ at a scanning rate of $0.02 \%$ for a $2 \theta$ range of 5-80. Scanning Electron Microscopy was done using an SEM (FEI Quanta 200 ESEM). Infrared was performed by FTIR-8400S. Analysis ICP was performed by AESJobinYvonUltima.

\subsection{Starting materials.}

Sulfuric acid $\left(\mathrm{H}_{2} \mathrm{SO}_{4} 98 \%\right)$ and phosphoric acid $\left(\mathrm{H}_{3} \mathrm{PO}_{4} 85 \%\right)$ were purchased from Sigma Aldrich, and the sodium hydroxide $(\mathrm{NaOH} 99 \%)$ was obtained from Prolabo. The phosphogypsum was provided from the Moroccan phosphate industry located in El Jadida, Morocco. The collected PG was dried at $80^{\circ} \mathrm{C}$, ground, and sieved through an $80 \mu \mathrm{m}$ sieve. The chemical composition of PG was evaluated by ICP analysis; major components and traces are summarized in Table 1. According to this data, the principal components of the $\mathrm{PG}$ are expressed as $\mathrm{CaO}$ and $\mathrm{SO}_{3}$; and the traces of $\mathrm{P}_{2} \mathrm{O}_{5} ; \mathrm{Al}_{2} \mathrm{O}_{3} ; \mathrm{Fe}_{2} \mathrm{O}_{3} ; \mathrm{K} 2 \mathrm{O}, \mathrm{F} ; \mathrm{MgO} ; \mathrm{Na}_{2} \mathrm{O}$, and $\mathrm{SiO}_{2}$.

Table 1. Chemical compositions of phosphogypsum derived from Moroccan phosphate (\%).

\begin{tabular}{l|l|l|l|l|l|l|l|l|l|l|l}
$\mathbf{C a O}$ & $\mathbf{S O}_{3}$ & $\mathbf{P}_{\mathbf{2}} \mathbf{O}_{5}$ & $\mathbf{C}$ & $\mathbf{A l}_{2} \mathbf{O}_{3}$ & $\mathbf{F e}_{2} \mathbf{O}_{3}$ & $\mathbf{K}_{2} \mathbf{O}$ & $\mathbf{F}$ & $\mathbf{M g O}$ & $\mathbf{N a}_{2} \mathbf{O}$ & $\mathbf{S i O}_{2}$ & Color \\
\hline 32.27 & 45.1 & 0.92 & 0.14 & 0.13 & 0.83 & 0.34 & 0.12 & 0.17 & 0.14 & 0.25 & Greenish-yellow
\end{tabular}

\subsection{Preparation of brushite powder.}

The brushite was synthesized using a sol-gel method following two principal steps. The first one is preparing the anhydrite from Moroccan phosphogypsum; the phosphogypsum waste was then treated using sulfuric acid $67 \%$ to obtain an anhydrite crystal. In the second step, 0.073 moles of anhydrite were mixed with $100 \mathrm{~mL}$ of distilled water and 0.058 moles of $\mathrm{H}_{3} \mathrm{PO}_{4}$. The solution was stirred at a speed of $500 \mathrm{rpm}$ for $48 \mathrm{H}$, and the $\mathrm{pH}$ was adjusted in a range of 6-7 by $\mathrm{NaOH}$. Brushite formation can be expressed by the following reaction (1):

$$
10 \mathrm{CaSO}_{4}+10 \mathrm{H}_{3} \mathrm{PO}_{4}+20 \mathrm{NaOH} \longrightarrow 10 \mathrm{CaHPO}_{4}, 2 \mathrm{H}_{2} \mathrm{O}+10 \mathrm{Na}_{2} \mathrm{SO}_{4}
$$

The resulting white suspension was then separated from the solution and washed with acetone. The resulting stochiometric brushite was dried at $105^{\circ} \mathrm{C}$ for 24 hours. The schema of the preparation of brushite powder is presented in Figure 1. 


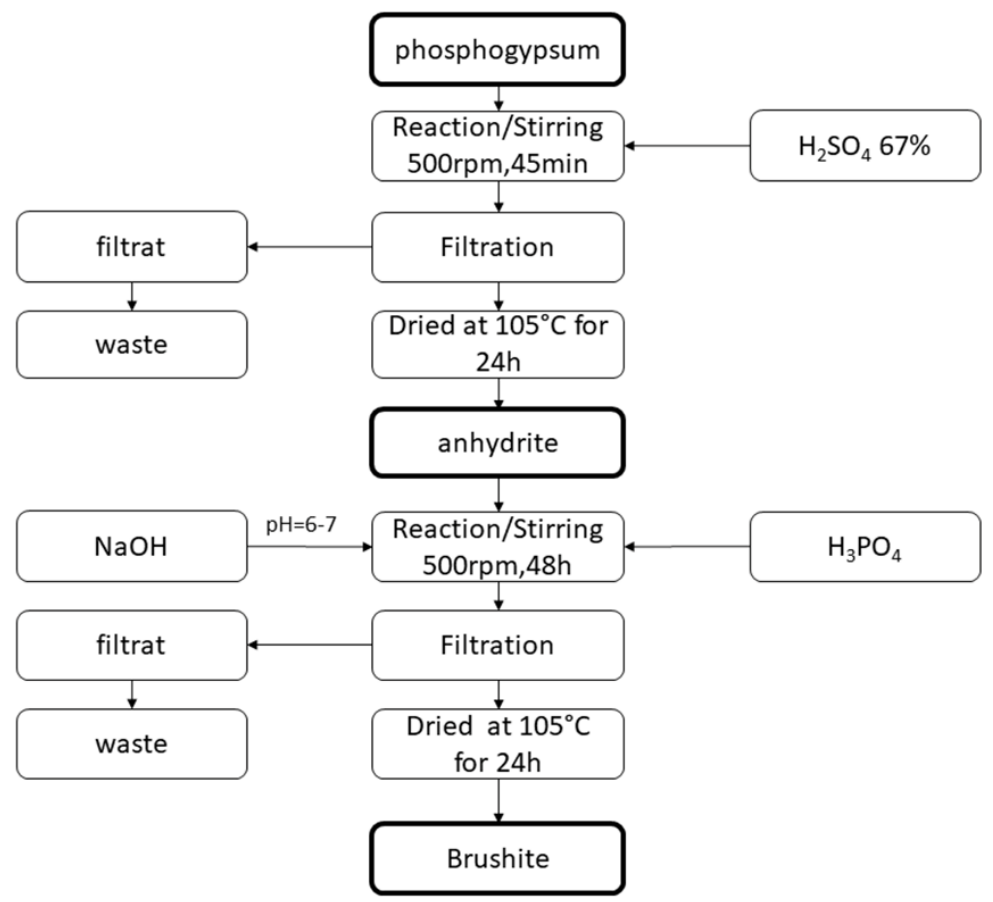

Figure 1. Diagram of preparing brushite particles from phosphogypsum.

\section{Results and Discussion}

\subsection{Characterization of brushite.}

\subsubsection{Chemical composition.}

Table 2 shows the chemical compositions of anhydrite and brushite performed by ICP. The main components of anhydrite are $\mathrm{CaO}$ and $\mathrm{SO}_{3}$ with $40.28 \%$ and $57.5 \%$, respectively, the $\mathrm{P}_{2} \mathrm{O}_{5}$, M.O, $\mathrm{Al}_{2} \mathrm{O}_{3}, \mathrm{Fe}_{2} \mathrm{O}_{3}$, and $\mathrm{SiO}_{2}$ present in the form of impurities with $\mathrm{pH} 4.23$. On the other hand, brushite is rich in $\mathrm{CaO}$ and $\mathrm{P}_{2} \mathrm{O}_{5}$ and poor in $\mathrm{SO}_{3}, \mathrm{Al}_{2} \mathrm{O}_{3}, \mathrm{Fe}_{2} \mathrm{O}_{3}$, and $\mathrm{SiO}_{2}$ with $\mathrm{pH}$ 7. The ratio of $\mathrm{Ca} / \mathrm{P}$ for brushite was 1.14 [15, 43-46].

Table 2. Chemical compositions of anhydrite and brushite (\%)

\begin{tabular}{l|c|c|c|c|c|c|c|c|c|c} 
Parameter & $\mathbf{C a O}$ & $\mathbf{S O}_{\mathbf{3}}$ & $\mathbf{P}_{\mathbf{2}} \mathbf{O}_{\mathbf{5}}$ & $\mathbf{M . O}$ & $\mathbf{A l}_{\mathbf{2}} \mathbf{O}_{\mathbf{3}}$ & $\mathbf{F e}_{\mathbf{2}} \mathbf{O}_{\mathbf{3}}$ & $\mathbf{M g O}$ & $\mathbf{S i O}_{\mathbf{2}}$ & $\mathbf{p H}$ & $\mathbf{C o l o r}$ \\
\hline Anhydrite & 40.28 & 57.50 & 0.20 & 0.0096 & 0.01 & 0.04 & 0.09 & 0.72 & 4.23 & White \\
\hline Brushite & 36.4 & 1.25 & 38.94 & - & 0.01 & 0.02 & 0.05 & 0.68 & 7 & White
\end{tabular}

\subsubsection{XRD analysis of brushite.}

Figure 2 shows the XRD patterns of brushite particles dried at $105^{\circ} \mathrm{C}$. The spectrum confirmed that the obtained product had higher crystallinity and was mainly composed of brushite. The results are in good agreement with the JCPDS file 009-0077 in peak position and peak intensity. The maximum peaks intensities were located at $2 \theta$ equal to $12^{\circ}, 21^{\circ}$, and $29^{\circ}$ these peaks were attributed to the Miller indices of $(020),(021)$, and $(111)[15,47]$. The observed diffraction peaks were related to DCPD, and no impurity phases were found. The particle size was calculated by the Scherer equation [45-47]:

$$
\mathrm{D}=\mathrm{K} \beta_{1 / 2} / \operatorname{Cos} \lambda \theta
$$

$\mathrm{D}$ is particle size $\left(\mathrm{A}^{\circ}\right), \mathrm{K}$ is $0.9, \lambda$ is the wavelength of $\mathrm{X}$-rays against $1.54056 \mathrm{~A}^{\circ}, \lambda$ is Bragg angle of the peak from diffraction, and $\beta_{1 / 2}$ is in terms of radians. 


$$
\beta_{1 / 2}=\left(\beta_{\mathrm{m}}^{2}-\beta_{\mathrm{s}}^{2}\right)
$$

Based on equations (2) and (3), the particle size of brushite was $66 \mathrm{~nm}$.

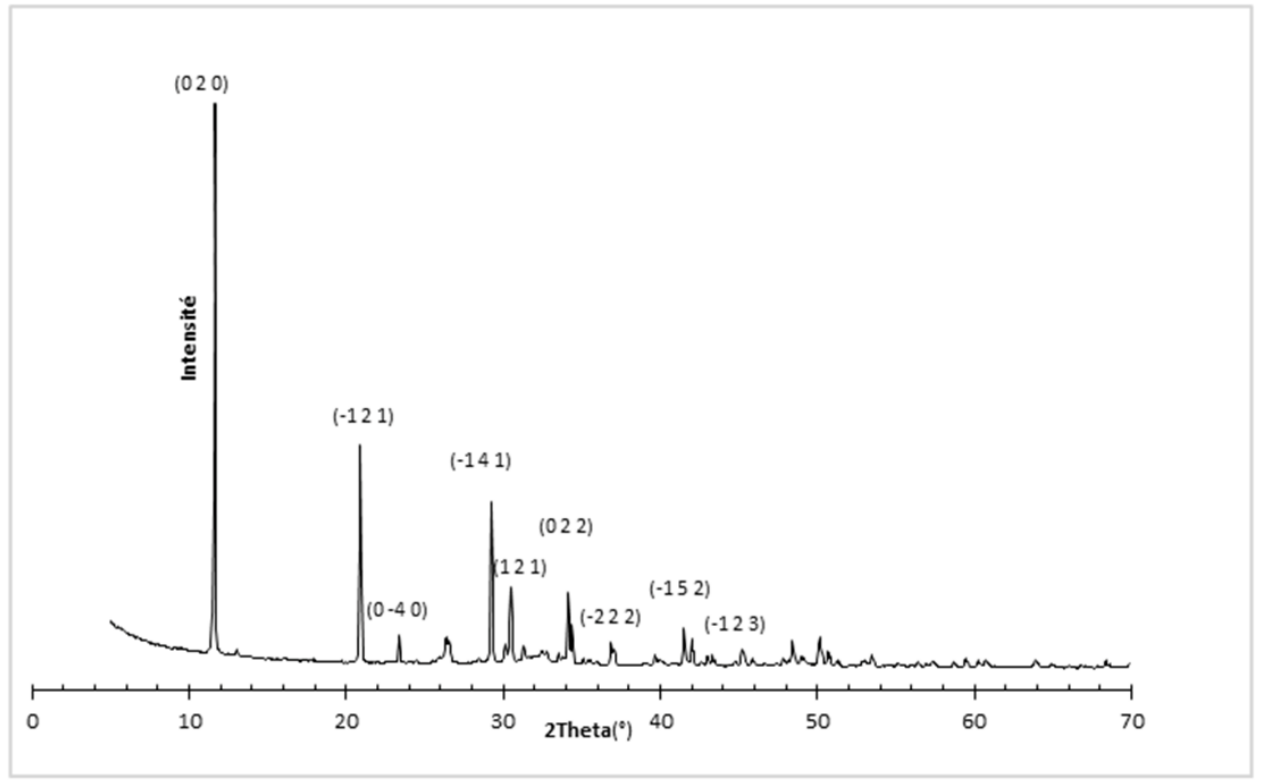

Figure 2. XRD spectra of brushite dried at $105^{\circ}$.

\subsubsection{FTIR of brushite.}

Figure 3 shows the infrared absorption spectra of brushite treatment at $105^{\circ} \mathrm{C}$. Bands located between 4000 and $1600 \mathrm{~cm}^{-1}, 4$ bands characteristics of the vibrations of two types of water molecules $\left(3537,3484,3292\right.$, and $3166 \mathrm{~cm}^{-1}$ ) were observed. The band at $2931 \mathrm{~cm}^{-1}$ corresponds to the $\mathrm{O}-\mathrm{H}$ elongation vibration of the $\mathrm{P}-(\mathrm{OH})$ entities. This allocation of tapes is in perfect agreement with the structural data previously reported. The band packet at about $2373 \mathrm{~cm}^{-1}$ is assigned to combination vibrations. The high band at $1648 \mathrm{~cm}^{-1}$ corresponds to the modes of deformation of water molecules. Bands between 1600 and $400 \mathrm{~cm}^{-1}$ grouped all the modes of vibrational elongations $\left(11245,1062,988 \mathrm{~cm}^{-1}\right)$ and deformations $(576,526$, and $410 \mathrm{~cm}^{-1}$ ) of the P-O bonds.

The band observed at $870 \mathrm{~cm}^{-1}$ corresponds to the elongation vibration of the $\mathrm{P}-(\mathrm{OH})$ bond. The other bands were assimilated to the shaking modes of the water molecules $\left(657 \mathrm{~cm}^{-}\right.$ $\left.{ }^{1}\right)$ and the in-plane and out-of-plane deformation of the O-H bonding of the $\left(\mathrm{HPO}_{4}\right)^{2-}(1213$ $\mathrm{cm}^{-1}$ and $790 \mathrm{~cm}^{-1}$ ) groups. This agrees well with FT-IR data of calcium hydrogen phosphate reported in the literature $[15,16,48,49]$.

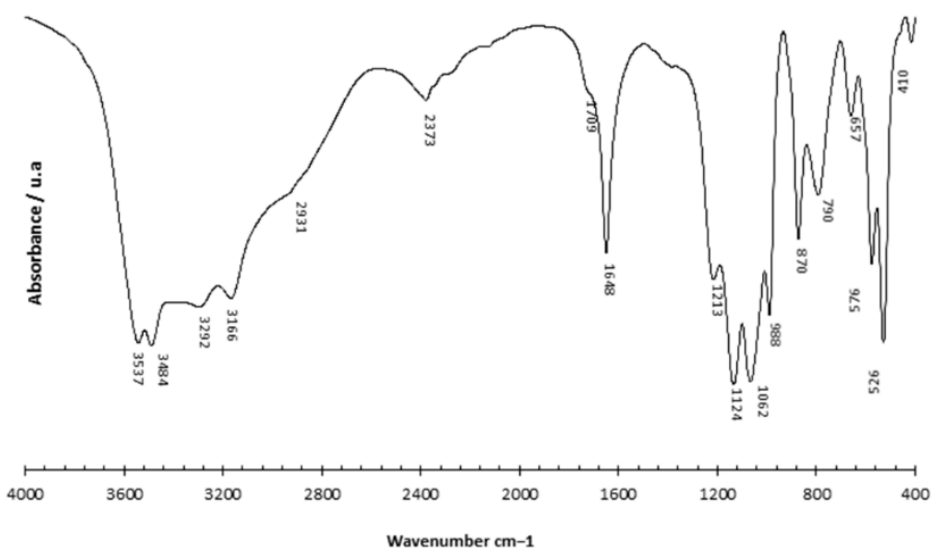

Figure 3. FTIR spectra of brushite dried at $105^{\circ}$. 


\subsubsection{Scanning Electron Microscopy of brushite.}

The micrographs in Figure 4 show our synthetized brushite dried at $105^{\circ} \mathrm{C}$ in different magnifications (20000X and 5000X). The results show that the particles are shaped like small plates based on the layered structure of brushite. The layers grow faster in two directions so that plates are formed. The edge lengths of these plates were determined to be between $60 \mathrm{~nm}$ and $66 \mathrm{~nm}[50]$.
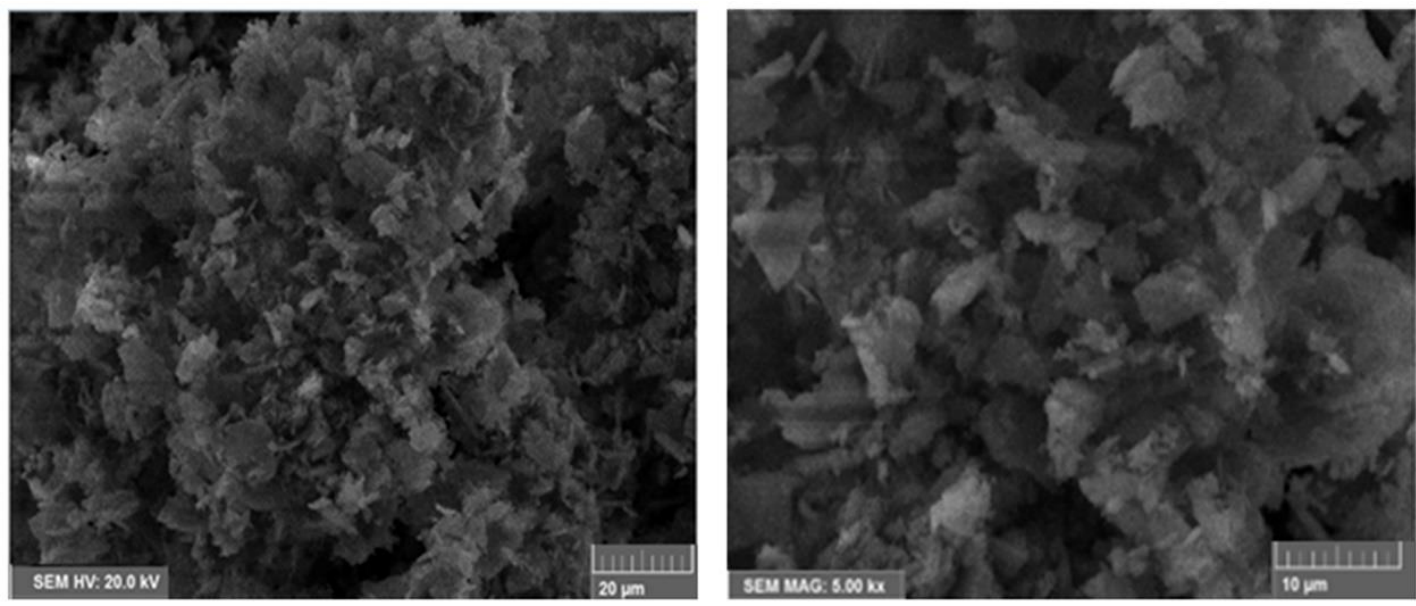

Figure 4. SEM images of brushite powder dried at $105^{\circ} \mathrm{C}$.

3.1.5. Energy dispersive X-ray of brushite.

The EDAX spectrum (Figure 5) confirms the presence of calcium $(\mathrm{Ca})$, phosphorus $(\mathrm{P})$, oxygen $(\mathrm{O})$, and a trace of $\mathrm{Na}$ in the stochiometric brushite sample. Chemical analysis of brushite shows the $\mathrm{Ca} / \mathrm{P}$ ratio is $1.14[15]$.

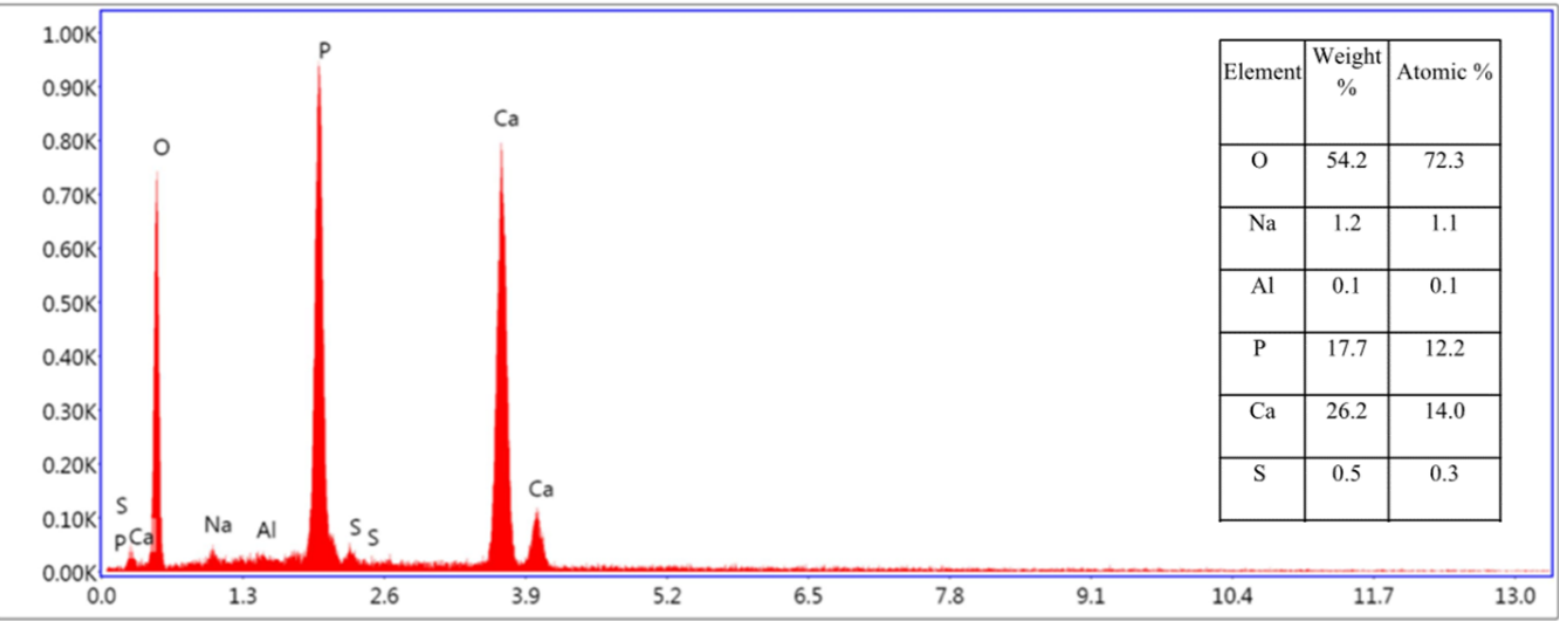

Figure 5. EDAX of brushite powder dried at $105^{\circ} \mathrm{C}$.

\section{Conclusions}

The brushite was synthesized by mixing anhydrite prepared from PG with phosphoric acid in the presence of Hydroxide sodium at room temperature. This DCPD was characterized by X-ray diffraction (XRD), Fourier transforms infrared spectroscopy (FTIR), Scanning Electron Microscopy (SEM), Energy-dispersive X-ray spectroscopy (EDAX).

The XRD and FTIR spectrum showed that the prepared DCPD was pure, and the size of the crystallites was estimated at $66 \mathrm{~nm}$. The EDAX spectrum of DCPD showed the existence of $\mathrm{Ca}, \mathrm{P}$, and $\mathrm{O}$ elements and the $\mathrm{Ca} / \mathrm{P}$ ratio value of 1.14 , which confirmed the formation of 
brushite. The EDAX and ICP result also established that the brushite crystals had a near theoretical chemical composition.

\section{Funding}

The authors have no affiliation with any organization with a direct or indirect financial interest in the subject matter discussed in the manuscript.

\section{Acknowledgments}

The authors gratefully acknowledge the Faculty of Science Semlalia, University of Cadi Ayyad, Morocco, for SEM analysis.

\section{Conflicts of Interest}

The authors declare no conflict of interest.

\section{References}

1. Young, A. M.; Ng, P. Y. J.; Gbureck, U.; Nazhat, S. N.; Barralet, J. E.; Hofmann, M. P. Characterization of Chlorhexidine-Releasing, Fast-Setting, brushite Bone Cements. Acta Biomater. 2008, 4, 1081-1088, https://doi.org/10.1016/j.actbio.2007.12.009.

2. Ginebra, M.-P.; Canal, C.; Espanol, M.; Pastorino, D.; Montufar, E. B. Calcium Phosphate Cements as Drug Delivery Materials. Adv. Drug Deliv. Rev. 2012, 64, 1090-1110, https://doi.org/10.1016/j.addr.2012.01.008.

3. Toshima, T.; Hamai, R.; Tafu, M.; Takemura, Y.; Fujita, S.; Chohji, T.; Tanda, S.; Li, S.; Qin, G. W. Morphology Control of brushite Prepared by Aqueous Solution Synthesis. J. Asian Ceram. Soc. 2014, 2, 52 56, https://doi.org/10.1016/j.jascer.2014.01.004.

4. Kawasaki, A.; Ishikawa, K.; Suge, T.; Shimizu, H.; Suzuki, K.; Matsuo, T.; Ebisu, S. Effects of Plaque Control on the Patency and Occlusion of Dentine Tubules in Situ. J. Oral Rehabil. 2001, 28, 439-449, https://doi.org/10.1046/j.1365-2842.2001.00682.x.

5. Zhou, H.; Yang, L.; Gbureck, U.; Bhaduri, S. B.; Sikder, P. Monetite, an Important Calcium Phosphate Compound-Its Synthesis, Properties and Applications in Orthopedics. Acta Biomater. 2021, 127, 41-55, https://doi.org/10.1016/j.actbio.2021.03.050.

6. Motameni, A.; Alshemary, A. Z.; Evis, Z. A Review of Synthesis Methods, Properties and Use of Monetite Cements as Filler for Bone Defects. Ceram. Int. 2021, 47, 13245-13256, https://doi.org/10.1016/j.ceramint.2021.01.240.

7. Gao, J.; Su, Y.; Qin, Y.-X. Calcium Phosphate Coatings Enhance Biocompatibility and Degradation Resistance of Magnesium Alloy: Correlating in Vitro and in Vivo Studies. Bioact. Mater. 2021, 6, 1223 1229, https://doi.org/10.1016/j.bioactmat.2020.10.024.

8. Yao, Q.; Jiang, Y.; Tan, S.; Fu, X.; Li, B.; Liu, L. Composition and Bioactivity of Calcium Phosphate Coatings on Anodic Oxide Nanotubes Formed on Pure Ti and Ti-6Al-4V Alloy Substrates. Mater. Sci. Eng. C 2020, 110, 110687, https://doi.org/10.1016/j.msec.2020.110687.

9. Laviano, R.; Fiore, S. brushite, Hydroxylapatite, and Taranakite from Apulian Caves (Southern Italy): New $\begin{array}{llllll}\text { Mineralogical Data. Am. } & \text { Mineral. }\end{array}$ https://pubs.geoscienceworld.org/msa/ammin/article-abstract/76/9-10/1722/105167/brushitehydroxylapatite-and-taranakite-from?redirectedFrom=fulltext.

10. Lee, I.-H.; Lee, J.-A.; Lee, J.-H.; Heo, Y.-W.; Kim, J.-J. Effects of PH and Reaction Temperature on Hydroxyapatite Powders Synthesized by Precipitation. J. Korean Ceram. Soc. 2020, 57, 56-64, https://doi.org/10.1007/s43207-019-00004-0.

11. Onac, B.; Veres, D. Sequence of Secondary Phosphates Deposition in a Karst Environment: Evidence from Măgurici Cave (Romania). Eur. J. Mineral. 2003, 15, 741-745, https://doi.org/10.1127/09351221/2003/0015-0741.

12. Budavari, S.; Co, M. \&. The Merck Index : An Encyclopedia of Chemicals, Drugs, and Biologicals, 12th ed.; Whitehouse Station, N.J. : Merck \& Co. Inc, 1996. 
13. Pina, S.; Ferreira, J. M. F. brushite-Forming Mg-, Zn- and Sr-Substituted Bone Cements for Clinical Applications. Materials 2010, 3, 519-535, https://doi.org/10.3390/ma3010519.

14. Lee, D.; Kumta, P. N. Chemical Synthesis and Stabilization of Magnesium Substituted brushite. Mater. Sci. Eng. C 2010, 30, 934-943. https://doi.org/10.1016/j.msec.2010.04.007.

15. Laskus-Zakrzewska, A.; Zgadzaj, A.; Kolmas, J. Synthesis and Physicochemical Characterization of ZnDoped brushite. Ceram. Int. 2021, 47, 7798-7804. https://doi.org/10.1016/j.ceramint.2020.11.125.

16. Sayahi, M.; Santos, J.; El-Feki, H.; Charvillat, C.; Bosc, F.; Karacan, I.; Milthorpe, B.; Drouet, C. brushite $(\mathrm{Ca}, \mathrm{M}) \mathrm{HPO}_{4}, 2 \mathrm{H}_{2} \mathrm{O}$ Doping with Bioactive Ions $(\mathrm{M}=\mathrm{Mg} 2+, \mathrm{Sr} 2+, \mathrm{Zn} 2+, \mathrm{Cu} 2+$, and Ag+): A New Path to Functional Biomaterials? Mater. Today Chem. 2020, 16, https://doi.org/10.1016/j.mtchem.2019.100230.

17. Boonchom, B.; Danvirutai, C. The morphology and thermal behavior of Calcium dihydrogen phosphate monohydrate $\left(\mathrm{Ca}\left(\mathrm{H}_{2} \mathrm{PO}_{4}\right) 2 \cdot \mathrm{H}_{2} \mathrm{O}\right)$ obtained by a rapid precipitation route at ambient temperature in different media. J. Optoelectron. Biomed. $\quad$ Mater $\quad$ 2009, https://citeseerx.ist.psu.edu/viewdoc/download?doi=10.1.1.1067.1881\&rep=rep1\&type=pdf.

18. Ma, M.-G.; Zhu, Y.-J.; Chang, J. Monetite Formed in Mixed Solvents of Water and Ethylene Glycol and Its Transformation to Hydroxyapatite. J. Phys. Chem. B 2006, 110, 14226-14230, https://doi.org/10.1021/jp061738r.

19. Kumar, R.; Prakash, K. H.; Cheang, P.; Khor, K. A. Temperature Driven Morphological Changes of Chemically Precipitated Hydroxyapatite Nanoparticles. Langmuir 2004, 20, 5196-5200, https://doi.org/10.1021/la049304f.

20. Zavala-Corrales, J. L.; Balandrán-Quintana, R. R.; Azamar-Barrios, J. A.; Mendoza-Wilson, A. M.; HurtadoSolórzano, P. G.; Pompa-Redondo, J. S. Wheat Bran Extracts as Biomineralization Scaffolds: An Exploratory Study Leading to Aqueous Solution Synthesis of Spheroidal brushite Particles. Food Bioprod. Process. 2020, 121, 238-249, https://doi.org/10.1016/j.fbp.2020.03.003.

21. Moussa, H.; Jiang, W.; Alsheghri, A.; Mansour, A.; Hadad, A. E.; Pan, H.; Tang, R.; Song, J.; Vargas, J.; McKee, M. D.; Tamimi, F. High Strength brushite Bioceramics Obtained by Selective Regulation of Crystal Growth with Chiral Biomolecules. Acta Biomater. 2020, 106, 351-359, https://doi.org/10.1016/j.actbio.2020.01.047.

22. Ahmed, M. K.; Afifi, M.; Mansour, S. F.; Ibrahium, H. A.; Aldulmani, S. A. A.; Awwad, N. S. Morphological Behaviors of brushite/Vivianite Nanocomposites and Their Potency for Se(IV) and Cd(II) Removal from $\begin{array}{llllll}\text { Aqueous Solutions. } & \text { Mater. } & \text { Chem. }\end{array}$ https://doi.org/10.1016/j.matchemphys.2020.124057.

23. Diez-Escudero, A.; Espanol, M.; Ginebra, M.-P. Chapter 5 - Synthetic Bone Graft Substitutes: CalciumBased Biomaterials. In Dental Implants and Bone Grafts; Alghamdi, H., Jansen, J., Eds.; Woodhead Publishing 2020, 125-157, https://doi.org/10.1016/B978-0-08-102478-2.00006-4.

24. Liu, D.-M.; Yang, Q.; Troczynski, T.; Tseng, W. J. Structural Evolution of Sol-Gel-Derived Hydroxyapatite. Biomaterials 2002, 23, 1679-1687. https://doi.org/10.1016/S0142-9612(01)00295-2.

25. Yao-ShanHsu'; EdwardChanga; Hok-ShinLiu ${ }^{\mathrm{b}}$. Hydrothermally-grown monetite $\left(\mathrm{CaHPO}_{4}\right)$ on hydroxyapatite, Ceramics International 249-254, https://www.sciencedirect.com/science/article/pii/S0272884296000569.

26. Gonzalez-McQuire, R.; Chane-Ching, J.-Y.; Vignaud, E.; Lebugle, A.; Mann, S. Synthesis and Characterization of Amino Acid-Functionalized Hydroxyapatite Nanorods. J. Mater. Chem. 2004, 14, 2277 , https://doi.org/10.1039/b400317a.

27. Han, J.-H.; Pack, S. P.; Chung, S. Solvo-Hydrothermal Synthesis of Calcium Phosphate Nanostructures from Calcium Inositol Hexakisphosphate Precursor in Water-Ethanol Mixed Solutions. Korean J. Chem. Eng. 2020, 37, 891-897, https://doi.org/10.1007/s11814-020-0496-3.

28. Feng, W.; Feng, C.; Wang, B.; Jing, A.; Li, G.; Xia, X.; Liang, G. An Amorphous Calcium Phosphate for Drug Delivery: ATP Provides a Phosphorus Source and Microwave-Assisted Hydrothermal Synthesis. Mater. Today Commun. 2020, 25, 101455, https://doi.org/10.1016/j.mtcomm.2020.101455.

29. Liu, J.; Li, K.; Wang, H.; Zhu, M.; Yan, H. Rapid Formation of Hydroxyapatite Nanostructures by Microwave Irradiation. Chem. Phys. Lett. 2004, 396, 429-432, https://doi.org/10.1016/j.cplett.2004.08.094.

30. Kong, X.-D.; Sun, X.-D.; Lu, J.-B.; Cui, F.-Z. Mineralization of Calcium Phosphate in Reverse Microemulsion. Curr. Appl. Phys. 2005, 5, 519-521, https://doi.org/10.1016/j.cap.2005.01.024. 
31. Rohanizadeh, R.; LeGeros, R. Z.; Harsono, M.; Bendavid, A. Adherent Apatite Coating on Titanium Substrate Using Chemical Deposition. J. Biomed. Mater. Res. A 2005, 72A, 428-438, https://doi.org/10.1002/jbm.a.30258.

32. Braga, J. de O.; de Carvalho, S. M.; Silva, L. M. C.; Soares, R. B.; Lins, V. F. C.; Mazzer, E. M.; Houmard, M.; Figueiredo, R. B.; Nunes, E. H. M. Fabrication and Characterization of Dicalcium Phosphate Coatings Deposited on Magnesium Substrates by a Chemical Conversion Route. Surf. Coat. Technol. 2020, 386, 125505, https://doi.org/10.1016/j.surfcoat.2020.125505.

33. Soliman, H.; Pu, S.; Zhang, W.; Makhlouf, A. S.; Wan, G. Deposition of Anti-Corrosion Hybrid Film of Hexamethylene Diaminetetrakis (Methylene Phosphonic Acid)/Hydroxyapatite on Biodegradable Mg: Influence of Deposition Procedures. Surf. Coat. Technol. 2020, 402, 126242, https://doi.org/10.1016/j.surfcoat.2020.126242.

34. Guo, Y.; Jia, S.; Qiao, L.; Su, Y.; Gu, R.; Li, G.; Lian, J. Enhanced Corrosion Resistance and Biocompatibility of Polydopamine/Dicalcium Phosphate Dihydrate/Collagen Composite Coating on Magnesium Alloy for

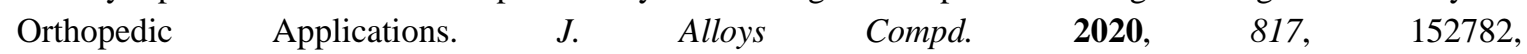
https://doi.org/10.1016/j.jallcom.2019.152782.

35. You, M.; Echeverry-Rendón, M.; Zhang, L.; Niu, J.; Zhang, J.; Pei, J.; Yuan, G. Effects of Composition and Hierarchical Structures of Calcium Phosphate Coating on the Corrosion Resistance and Osteoblast Compatibility of $\mathrm{Mg}$ Alloys. Mater. Sci. Eng. C 2021, 120, 111734, https://doi.org/10.1016/j.msec.2020.111734.

36. Djošić, M. S.; Mišković-Stanković, V. B.; Kačarević-Popović, Z. M.; Jokić, B. M.; Bibić, N.; Mitrić, M.; Milonjić, S. K.; Jančić-Heinemann, R.; Stojanović, J. Electrochemical Synthesis of Nanosized Monetite Powder and Its Electrophoretic Deposition on Titanium. Colloids Surf. Physicochem. Eng. Asp. 2009, 341, 110-117, https://doi.org/10.1016/j.colsurfa.2009.03.046.

37. Shahmohammadi, P.; Khazaei, B. A. Characterization of $\mathrm{Zn} / \mathrm{Mg}$-Enriched Calcium Phosphate Coating Produced by the Two-Step Pulsed Electrodeposition Method on Titanium Substrate. Surf. Interfaces 2021, 22, 100819, https://doi.org/10.1016/j.surfin.2020.100819.

38. Mi, X.; Gupte, M. J.; Zhang, Z.; Swanson, W. B.; McCauley, L. K.; Ma, P. X. Three-Dimensional Electrodeposition of Calcium Phosphates on Porous Nanofibrous Scaffolds and Their Controlled Release of Calcium for Bone Regeneration. ACS Appl. Mater. Interfaces 2020, 12, 32503-32513, https://doi.org/10.1021/acsami.0c11003.

39. Xue, J.; Farris, A.; Wang, Y.; Yeh, W.; Romany, C.; Guest, J. K.; Grayson, W. L.; Hall, A. S.; Weihs, T. P. Electrodeposition of Hydroxyapatite on a Metallic 3D-Woven Bioscaffold. Coatings 2020, 10, 715, https://doi.org/10.3390/coatings10080715.

40. Kyung Hee Park; Ho-Jun Song and Yeong-Joon Park*. Department of Dental Materials and Hard-tissue Biointerface Research Center, School of Dentistry, Chonnam National University, Gwangju 61186, Korea; Hee Park, K. Calcium Phosphate-Chitosan Coatings Deposited on Titanium Surfaces via Pulse Galvanostatic Electrodeposition for Dental Implants. Int. J. Electrochem. Sci. 2020, 9611-9621, https://doi.org/10.20964/2020.10.73.

41. Suchanek, W. L.; Shuk, P.; Byrappa, K.; Riman, R. E.; TenHuisen, K. S.; Janas, V. F. MechanochemicalHydrothermal Synthesis of Carbonated Apatite Powders at Room Temperature. Biomaterials 2002, 23, 699710, https://doi.org/10.1016/S0142-9612(01)00158-2.

42. Liu, C.; Huang, Y.; Shen, W.; Cui, J. Kinetics of Hydroxyapatite Precipitation at PH 10 to 11. Biomaterials 2001, 22, 301-306, https://doi.org/10.1016/S0142-9612(00)00166-6.

43. Sivakumar, G. R.; Girija, E. K.; Narayana Kalkura, S.; Subramanian, C. Crystallization and Characterization of Calcium Phosphates: brushite and Monetite. Cryst. Res. Technol. 1998, 33, 197-205, https://doi.org/10.1002/(SICI)1521-4079(1998)33:2<197::AID-CRAT197>3.0.CO;2-K.

44. Laniesse, P.; Cau Dit Coumes, C.; Le Saout, G.; Mesbah, A. Understanding the Setting and Hardening Process of Wollastonite-Based brushite Cement. Part 1: Influence of the $\mathrm{Ca} / \mathrm{P}$ Ratio and H3PO4 Concentration of the Mixing Solution. Cem. Concr. Res. 2020, 134, 106094, https://doi.org/10.1016/j.cemconres.2020.106094.

45. Laniesse, P.; Cau Dit Coumes, C.; Le Saout, G.; Mesbah, A. Understanding the Setting and Hardening Process of Wollastonite-Based brushite Cement. Part 2: Influence of the Boron and Aluminum Concentrations in the Mixing Solution. Cem. Concr. Res. 2021, 140, 106288, https://doi.org/10.1016/j.cemconres.2020.106288.

46. El Hazzat, M.; El Hamidi, A.; Halim, M.; Arsalane, S. Complex Evolution of Phase during the Thermal Investigation of brushite-Type Calcium Phosphate CaHPO4•2H2O. Materialia 2021, 16, 101055, https://doi.org/10.1016/j.mtla.2021.101055. 
47. Maity, J. P.; Lin, T.-J.; Cheng, H. P.-H.; Chen, C.-Y.; Reddy, A. S.; Atla, S. B.; Chang, Y.-F.; Chen, H.-R.; Chen, C.-C. Synthesis of brushite Particles in Reverse Microemulsions of the Biosurfactant Surfactin. Int. J. Mol. Sci. 2011, 12, 3821-3830, https://doi.org/10.3390/ijms12063821.

48. Rachid Ekm: Billah, R.E.K.; Abdellaoui, Y.; Anfar, Z.; Giácoman-Vallejos, G.; Agunaou, M.; Soufiane, A. Synthesis and Characterization of Chitosan/Fluorapatite Composites for the Removal of Cr (VI) from Aqueous Solutions and Optimized Parameters. Water Air Soil Pollut 2020, 231, 163, https://doi:10.1007/s11270-020-04535-9.

49. Nosrati, H.; Le, D. Q. S.; Zolfaghari Emameh, R.; Canillas Perez, M.; Bünger, C. E. Nucleation and Growth of brushite Crystals on the Graphene Sheets Applicable in Bone Cement. Bol. Soc. Esp. Cerámica Vidr. 2020. https://doi.org/10.1016/j.bsecv.2020.05.001.

50. Betke, A.; Kickelbick, G. Bottom-Up, Wet Chemical Technique for the Continuous Synthesis of Inorganic Nanoparticles. Inorganics 2014, 2, 1-15. https://doi.org/10.3390/inorganics2010001. 